\title{
The Curious Incident of Trump AND the Courts: InTERBRANCH DefERENCE IN AN Age OF Populism
}

\author{
Bruce G. Peabody*
}

\begin{abstract}
Given President Donald Trump's generally non-deferential posture towards national political and governing institutions, why hasn't his administration produced greater tension with respect to judges, courts, and established norms of judicial independence? Increased politicization of the judiciary, deepening partisanship, and distinct attributes of the President himself all seem to set up a climate of interbranch confrontation likely to challenge judicial independence norms. But at least in the first two years of this presidency, sustained opposition to courts is not evident. This analysis documents and accounts for this puzzle, ultimately contending that the President's unexpected (and admittedly fragile) institutional comity can be traced to his personal history of relying on legal safeguards and authority as well as a complex stew of partisan and ideological uncertainty about the future direction of courts.
\end{abstract}

\section{KEYWORDS}

Comity, Federal Courts, Judicial Independence, Judicial Politics, Partisanship, Populism, Separation of Powers, Trump

\section{CONTENTS}

I. The Recent Context of Interbranch Conflict ...........................238

A. The Politicization of Courts ....................................................2239

B. The Rise of Hyper-Partisanship ..............................................240

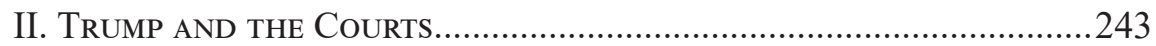

A. Personalization of Politics ......................................................243

B. The President's Populist Iconoclasm .......................................245

III. Accounting for Presidential Deference ....................................246

A. Executive Interests and Independent Courts.............................249

B. Personal Familiarity and Past Reliance....................................250

C. Partisan Disequilibrium and the Courts ..................................251

IV. ForeCASTING THE FUtURE........................................................254

* Professor of Political Science, Fairleigh Dickinson University, Madison, New Jersey, B.A., 1991, Wesleyan University, Ph.D., 2000, University of Texas at Austin. This article is based, in part, on a working paper presented at the 2017 American Society of Criminology Annual Conference in Philadelphia; the author thanks Michael Stile for his invaluable research assistance, Sheldon Goldman for sharing research, the Becton College Dean's Office for travel support, and Elizabeth Brown, Jaime Henderson, Hon. Roderick Ireland, and John Kramer, for their comments and insights. 
Given President Donald Trump's generally non-deferential and even antagonistic posture towards national political and governing institutions, why hasn't his administration produced greater tension with respect to judges, courts, and established norms of judicial independence? To be sure, the President has prominently tussled with the federal judiciary in connection with immigration policy (especially regarding the administration's socalled "travel ban" on immigrants and refugees from majority-Muslim countries), and he has accused courts of being "slow and political."1 The President has singled out individual decisions for rebuke, especially regarding what he considers lenient sentencing, such as in the case of Bowe Bergdahl, a U.S. soldier who deserted his post in Afghanistan in 2009 and was subsequently captured by the Taliban. ${ }^{2}$ And Trump has targeted the Ninth Circuit Court of Appeals in particular as having a "terrible record of being overturned" and serving as the source of "outrageous" decisions. ${ }^{3}$

But, on the whole, these reproaches have represented the exception rather than the rule. The President has stepped somewhat lightly around the courts, especially in comparison with his more aggressive posture towards other institutions, such as the press and intelligence community. At least in the first two years of the Trump White House, sustained opposition to courts is the proverbial dog that didn't bark-a surprising outcome given numerous factors inclining us towards heightened executivejudicial tension, and the clamorous noises otherwise emerging from the bully pulpit.

The following analysis tries to both document and account for this puzzle. I consider and probe a variety of hypotheses for why an iconoclastic and populist President Trump, otherwise suspicious if not outright hostile to governing institutions and their elite leaders, appears to be reticent to take on the judiciary, at least in any consistent or sweeping manner. Ultimately, I contend, a plausible explanation for the President's unexpected (and admittedly fragile) institutional comity can be traced to Trump's personal history of relying on legal safeguards and authority, and the complex and still bubbling stew of partisan and ideological uncertainty about the future direction of courts and parties. More broadly, this article provides a framework for understanding the separation of powers in an age of hyper-partisanship and anticipating the consequences of the inevitable future collisions between the administration's political imperatives, the courts' judgments, and the broad course of public policy hashed out in the nation's capital and fifty states.

\section{The Recent Context of InTERbranch Conflict}

An initial expectation that the Trump administration's relations with courts are likely to be strained can be traced to two primary sources: broad trends in interbranch

Brennan Center for Justice, In His Own Words: The President's Attacks on the Courts, Jun. 5, 2017, https://www.brennancenter.org/analysis/his-own-words-presidents-attacks-courts.

2 Merrit Kennedy, Bowe Bergdahl's Sentence: No Prison Time, NPR, Nov. 3, 2017, https:// www.npr.org/sections/thetwo-way/2017/11/03/561852721/bowe-bergdahls-sentenceno-prison-time.

3 Derek Hawkins, Trump Takes up GOP Tradition of Bashing 9th Circuit, a.k.a. '9th Circus, ' Wash. Post, Apr. 27, 2017, https://www.washingtonpost.com/news/morning$\mathrm{mix} / \mathrm{wp} / 2017 / 04 / 27 /$ trump-takes-up-hoary-gop-tradition-of-bashing-9th-circuit-aka9th-circus/?noredirect $=$ on\&utm_term $=.20 \mathrm{a} 3 \mathrm{e} 27 \mathrm{~d} 5 \mathrm{a} 9 \mathrm{f}$. 
politics, fueled especially by deepening partisanship over the past several decades, and factors more closely tethered to the President's distinctive governance style.

\section{A. The Politicization of Courts}

We might first observe that the twenty-first century ushered in an era of greater politicization with respect to the judiciary, that is, a greater willingness by public officials (especially Republicans) to place judges, cases, and other judicial issues at the forefront of policy debates, national political discourse, and campaign rhetoric and fundraising appeals. ${ }^{4}$ We find evidence of this in individual, politically salient confrontations over the past two decades, such as in 2005 when House Majority Leader Tom DeLay singled out Supreme Court Justice Anthony Kennedy's juvenile death penalty opinion Roper $v$. Simmons ${ }^{5}$ as "a good ground of impeachment."

But criticism of the courts for political gain has been more prevalent and systematic. Consider that from 2004-2008, four out of five of President George W. Bush's State of the Union addresses included prominent criticism of the courts, including his 2008 warning about judges who rule by "the whim of the gavel" rather than "the letter of the law." In Congress, proposals to "curb" or limit the traditional powers and prerogatives of courts surged significantly in the early 2000 s, averaging just over 13 such proposals every year from 2003-2008 (as opposed to an average of 4.4 proposals from 1984-2002). ${ }^{8}$ Scholars like Mark Miller have surveyed this recent landscape and concluded that we've entered a new phase of especially combative relations with the judiciary, driven by conservative interest groups and Republican "lawyer-legislators" on the House Judiciary Committee (previously the site of vigorous defense of judges and judicial independence). ${ }^{9}$ If Miller and comparable observers are correct, one might imagine that President Trump would be eager to contribute to this environment in which criticisms of courts are routine. ${ }^{10}$ After all, the President has shown no qualms in taking up attacks on the legislative and executive branches — both before and during his administration. ${ }^{11}$ Moreover, as already noted, the judiciary has periodically frustrated the President's stated policy

4 Mark C. Miller, The View of the Courts from the Hill (2009); C. Boyden Gray et al., Panel Discussion: Judicial Independence: Justifications \& Modern Criticisms, Georgetown University Law Center on Fair and Independent Courts: A Conference on the State of the Judiciary, Sep. 28, 2006, http:/www.law.georgetown.edu/news/documents/CoJ092806panel1.pdf, 2006; Sandra Day O'Connor, The Threat to Judicial Independence, WaLL ST. J., Sept. 27, 2006, at A18; James Sample et al., The New Politics of Judicial Elections, 2000-2009: Decade of Change, Brennan Center for Justice, Aug. 16, 2010, https://www. brennancenter.org/sites/default/files/legacy/JAS-NPJE-Decade-ONLINE.pdf.

5543 U.S. 551 (2005).

6 Dana Milbank, And the Verdict on Justice Kennedy Is: Guilty, WASH. Post, April 9, 2005, at $\mathrm{A} 03$.

7 The Politics of Judicial Independence: Courts, Politics, and the Public 8 (Bruce Peabody ed., 2011) (hereinafter The Politics of Judicial IndePendence).

$8 \quad$ Id. at 8.

$9 \quad$ MiLleR, supra note 4.

10 The Politics of Judicial IndePENDEnCE, supra note 7.

11 Katie Benner, Sessions Silent as Trump Attacks His Department, Risking Its Autonomy, N.Y. Times, February 5, 2018, at A14; Lisa Mascaro, Trump again bashes the Republican leaders in Congress he needs to pass his agenda, L.A. Times, August 24, 2017. 
goals, including, most famously, a series of rulings against the President's so-called "Muslim ban" and his "extreme vetting" executive orders. ${ }^{12}$

\section{B. THE RISE OF HYPER-PARTISANSHIP}

These claims feed directly to a second, interrelated point: the nation's thickening atmosphere of hyper-partisanship also makes executive-judicial confrontations more likely. Trump came to power in an era of deepening partisan division. ${ }^{13}$ Scholars have demonstrated the rise of elite level party polarization since the 1980s, including, by some measures, greater party conflict inside Congress today than at any point in the post-World War II period. ${ }^{14}$ This enflamed partisanship has impacted U.S. national politics and triggered disputes between all three branches of national government. ${ }^{15}$ At a minimum, an increasingly polarized set of political leaders are more likely to react to court cases, individual judges, and judicial nominations that have a salient partisan dimension - as identified by leaders, major party statements, important ideological interest groups, and, perhaps, by sharp divisions amongst judges themselves. ${ }^{16}$ Indeed some evidence of this influence of polarization on party leaders' attitudes towards courts can be found in party platforms, where we find steady and growing interest in courts and judicial decisions as a source of political fodder (see Table 1).

With respect, specifically, to the Trump administration's attitudes towards the judiciary in this atmosphere of heightened partisanship, we can further posit that tensions between the executive branch and courts are likely to intensify when a president inherits a court system that has been staffed by predecessors of a different

12 Michael D. Shear \& Ron Nixon, Vetting Is Little Changed Since Calls for Travel Ban, N.Y. Times, June 12, 2017, at A14.

13 Marc J. Hetherington \& Thomas J. Rudolph, Why Washington Won't Work: Polarization, Political Trust, and the Governing Crisis (2015).

14 Sarah A. Binder, Stalemate: Causes and Consequences of Legislative Gridlock (2003); Marc J. Hetherington \& Jonathan D. Weiler, Authoritarianism and Polarization in American Politics (2009); Frances E. Lee, Beyond Ideology: Politics, Principles, and Partisanship in the U.S. Senate (2009); Keith T. Poole \& Howard Rosenthal, Congress: A Political-Economic History of Roll Call Voting (1997); Sean M. Theriault, Party Polarization in Congress (2008). Others have contended there is a comparable partisan and ideological split in the public. See, e.g., Alan J. Abramowitz, The Polarized Public: Why American Government is so Dysfunctional (2012); Shanto Iyengar \& Sean J. Westwood, Fear and Loathing across Party Lines: New Evidence on Group Polarization, 59 Am. J. PoL. Scr. 690 (2015); Gary C. Jacobson, Partisan and Ideological Polarization in the California Electorate, 4 ST. PoL. \& PoliCY Q. 113 (2004). A countercurrent of research has downplayed the extent of this mass polarization. Morris P. Fiorina, Samuel J. Abrams \& Jeremy C. Pope, Culture War? The Myth of a Polarized America (2004).

15 Charles Gardner Geyh, When Courts and Congress Collide: The Struggle for Control of America's Judicial System (2008); Hetherington \& Rudolph, supra note 13; Barbara Sinclair, Party Wars: Polarization and the Politics of National Policy Making (2006); Mark Jonathan McKenzie, The Influence of Partisanship, Ideology, and the Law on Redistricting Decisions in the Federal Courts, 65 POL. RES. Q.

16 Adam Liptak, The Polarized Court, N.Y. Times, May 11, 2014, at SR1. 
Table 1. Party Platforms Highlighting Judicial Issues and Cases (2000-2016).

\begin{tabular}{|c|c|c|}
\hline Year & Democratic Platform & Republican Platform \\
\hline 2000 & $\begin{array}{l}\text { - "right to privacy" and abortion } \\
\text { - Olmstead v. L.C. }\end{array}$ & $\begin{array}{l}\text { - criticism of Supreme Court ruling on partial birth } \\
\text { abortion } \\
\text { - Communications Workers of America v. Beck } \\
\text { - criticism of "exclusionary rule" } \\
\text { - Utah v. Evans } \\
\text { - support for student initiated prayer } \\
\text { - criticism of "judicial activism" }\end{array}$ \\
\hline 2004 & & $\begin{array}{l}\text { - Elk Grove Unified v. Newdow } \\
\text { - Van Orden v. Perry } \\
\text { - protecting Defense of Marriage Act from courts } \\
\text { - partial birth abortion } \\
\text { - student initiated prayer }\end{array}$ \\
\hline 2008 & - Boumediene v. Bush & $\begin{array}{l}\text { - immigration decisions making "deportation so difficult" } \\
\text { - Kelo v. City of New London } \\
\text { - Boumediene v. Bush } \\
\text { - death penalty } \\
\text { - abortion } \\
\text { - D.C. v. Heller } \\
\text { - ROTC access case }\end{array}$ \\
\hline 2012 & $\begin{array}{l}\text { - Citizens United v. FEC } \\
\text { - using courts to protect } \\
\text { immigration rights }\end{array}$ & $\begin{array}{l}\text { - Knox v. Service Employees International Union, Local } \\
1000 \\
\text { - gay marriage/DOMA } \\
\text { - Hosanna Tabor v. EEOC } \\
\text { - public display of Ten Commandments } \\
\text { - student prayer } \\
\text { - BSA v. Dale } \\
\text { - Wisconsin Right to Life v. Federal Election Commission } \\
\text { - Citizens United v. Federal Election Commission } \\
\text { - No regulation of internet speech } \\
\text { - DC v. Heller } \\
\text { - McDonald v. Chicago } \\
\text { - Kelo } \\
\text { - abortion } \\
\text { - criticism of using foreign law in the courts } \\
\text { - NFIB v. Sebelius }\end{array}$ \\
\hline 2016 & $\begin{array}{l}\text { - criticism of courts' role in } \\
\text { mass incarceration } \\
\text { - praise for drug courts and } \\
\text { veterans' courts } \\
\text { - praise for Obergefell v. } \\
\text { Hodges } \\
\text { - criticism of Shelby County } \\
\text { v. Holder; Citizens United; } \\
\text { Buckley v. Valeo }\end{array}$ & $\begin{array}{l}\text { - Whole Woman's Health v. Hellerstedt } \\
\text { - United States } v \text {. Windsor } \\
\text { - criticism of judicial activism } \\
\text { - reliance on foreign law } \\
\text { - support for Citizens United and McCutcheon v. FEC } \\
\text { - Kelo } \\
\text { - support for State of Wyoming v. Jewell } \\
\text { - Sebelius } \\
\text { - criticism of Obergefell }\end{array}$ \\
\hline
\end{tabular}

Source: The American Presidency Project (http://www.presidency.ucsb.edu/) 
party and ideological orientation. ${ }^{17}$ Despite what scholars have documented as the "unprecedented level of obstruction and delay"18 President Barack Obama faced with his judicial nominations (especially after Republicans took over the Senate in 2015), he was still able to seat over 300 Article III judges over his two terms (see Figure 1). In this way, Obama shifted a federal judicial system that was in solid Republican control in 2004 to one with a narrow majority of Democratic appointees. As Slotnick, Goldman, and Schiavoni report, "[f]rom the start of Obama's tenure to the end, the cohort of judges appointed by Democrats increased from 39.1\% to $51.6 \%$." 19 As a further measure of Obama's impact in tightening the partisan division on the federal courts, consider that in 2009, Obama faced nine out of twelve Circuit Courts of Appeals (excluding the federal circuit) with Republican-appointed majorities, but when he left office only four Circuits had Republican majorities. ${ }^{20}$ To put all this in balder terms, when Mr. Trump took his oath of office in January 2017, the federal courts were the only branch of government not obviously held by

Figure 1. Percentage of President's nominees who were appointed (District Court and Circuit Court judges): 95 through $114^{\text {th }}$ Congresses (1977-2017).

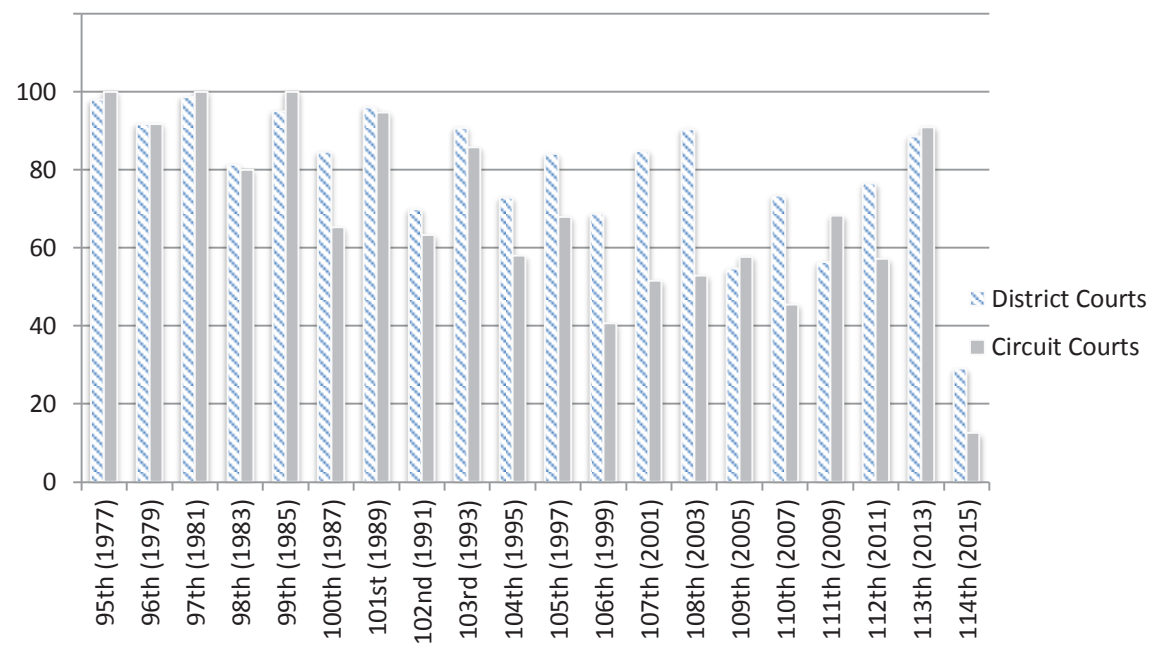

Source: Slotnick, Schiavoni, \& Goldman, supra note 18.

7 Robert A. Dahl, Decision-Making in a Democracy: The Supreme Court as a National Policy-Maker, 6 J. PuB. L. 279 (1957); Richard Funston, The Supreme Court and Critical Elections, 69 Am. Pol. SCI. Rev. 795 (1975); John B. Gates, Supreme Court Voting and Realigning Issues: A Microlevel Analysis of Supreme Court Policy Making and Electoral Realignment, 13 Soc. ScI. Hist. 255 (1989); Keith E. Whittington, "Interpose Your Friendly Hand": Political Supports for the Exercise of Judicial Review by the United States Supreme Court, 99 Am. PoL. SCI. Rev. 583 (2005).

18 Elliot Slotnick, Sara Schiavoni \& Sheldon Goldman, Obama's Judicial Legacy: The Final Chapter, 5 J. L. CourTs 363 (2017).

19 Id. at 410.

$20 \quad I d$. at 414. 
his party, and, therefore, they would seem positioned as a source of ongoing conflict and policy strain during the Trump years to come. ${ }^{21}$

\section{TRUMP AND THE COURTS}

Beyond these general assertions about why recent political trends set up the Trump administration for contentious relationships with courts, we can isolate additional aggravating factors more idiosyncratic to the incumbent president. The first of these is Mr. Trump's observed personalization of politics - a phenomenon with several dimensions.

\section{A. Personalization of Politics}

The President and his subordinates frequently conflate political legitimacy and proper public service with individual loyalty. ${ }^{22}$ To cite just one extraordinary example, in a press briefing from July 2017, the newly appointed Press Secretary Sarah Sanders and the short-lived White House Communications Director Anthony Scaramucci repeatedly expressed their "loyalty" to the President, along with their personal affection and even "love" for one another as well as the Commander in Chief. As Scaramucci elaborated:

...I love the President, and I'm very, very loyal to the President. And I love the mission that the President has, okay? Since the early days of the campaign...I saw the love that the people had for the President. ${ }^{23}$

Numerous commentators have seized on the continuing centrality of this loyalty value for a man who built both his presidential campaign (and prior business empire) on family and personal connections. ${ }^{24}$

The other, closely related aspect of the President's personalization approach is a tendency to entangle policies and people - to treat as fungible the perceived (de)merits, value, and feasibility of different program goals and the alleged virtues (or vices) of the specific individuals backing them. President Trump has expressed

$21 \quad$ After the 2016 elections, Republicans also had 33 state legislatures in their control. Eric Boehm, Democrats Got Wrecked Again in State Legislative Races, and it Matters More Than You Might Think, ReAson, Nov. 14, 2016, https://reason.com/blog/2016/11/14/the2016-election-turned-more-state-legi.

22 Michael McFaul, Why Trump's Personalized Approach to Diplomacy Is Bad for America, Wash. Post, June 28, 2018, https:/www.washingtonpost.com/news/globalopinions/wp/2018/06/28/why-trumps-personalized-approach-to-diplomacy-is-bad-foramerica/?utm term $=.4$ a 78 be $96337 \mathrm{~d}$.

23 The White House, Press Briefing By White House Principal Deputy Press Secretary Sarah Sanders and Incoming White House Communications Director Anthony Scaramucci, Jul. 21, 2017, https://www.whitehouse.gov/briefings-statements/pressbriefing-white-house-principal-deputy-press-secretary-sarah-sanders-incoming-whitehouse-communications-director-anthony-scaramucci-072117/.

24 Rob Crilly, Donald Trump Values Loyalty above All Else. That Has Made Him Very Vulnerable, TelegraPh, November 24, 2017, https://www.telegraph.co.uk/ news/2017/11/24/donald-trump-values-loyalty-else-could-undoing/. 
this idea with respect to himself on numerous occasions, perhaps most famously in his acceptance speech at the 2016 Republican National Convention (RNC). Here he declared to the American people "I am your voice" for delivering change to everyone who has "been neglected, ignored, and abandoned" and "crushed by our horrible and unfair trade deals." As Trump further explained, only he was qualified to repair a "rigged" political system: "[n]obody knows the system better than me, which is why I alone can fix it." 25

After being inaugurated, the President continued with this theme and celebrated political allies by recognizing their individual attributes as much as their skill, experience, or policy acumen. Thus he praised Attorney General Jeff Sessions as "an honest man," Fox News talk show host Sean Hannity as a "great guy (with great ratings)!" and lauded Supreme Court nominee Neil Gorsuch as someone who would fill the "mold" of deceased Justice Antonin Scalia. This personalization approach has also extended to the President's opponents. Indeed, many of the President's major early policy initiatives have targeted legislation or programs identified with his predecessor, including efforts to repeal the Patient Protection and Affordable Care Act ("Obamacare"), the termination of the Deferred Action for Childhood Arrivals (DACA) program, and the reversal of Obama administration criminal justice reform efforts. These moves have been justified less in terms of establishing a new policy path than in eradicating the destructive choices of others, including Mr. Obama, whom Trump called "perhaps the worst president in the history of the United States." 26

This blurring of personal and political authority is likely to trigger friction with courts for several reasons. Perhaps most obviously, a personalized approach will tend to see unfavorable court judgments as direct attacks, or instances of disloyalty, rather than principled and impersonal judgments of law. More generally, individualized and personality-driven claims to rule are at odds with both the notion that ours is a "government of separated institutions sharing powers" and customary understandings of the rule of law. ${ }^{27}$ In this traditional conception, law is impersonal, prospective, and stable - traits that jar against the personalization of politics embodied in much of the President's rhetoric. To take just one example of this disjuncture, consider Mr. Trump's remark during a 2016 campaign event that he could "stand in the middle of 5th Avenue and shoot somebody and I wouldn't lose voters." ${ }^{28}$ The statement suggested that even an extreme violation of law would not diminish voters' intimate ties to, and faith in, the candidate.

Interestingly, in those instances where the President has pushed most aggressively against individual judges, independence norms, and regular judicial

$25 \quad$ Full transcript available at: https://www.vox.com/2016/7/21/12253426/donald-trumpacceptance-speech-transcript-republican-nomination-transcript (accessed 11 Sept. 2018).

26 Donald J. Trump, President Obama Will Go Down as Perhaps the Worst President in the History of the United States! Twitter (Aug. 2, 2016, 12:07 PM), https://twitter.com/ realdonaldtrump/status/760552601356267520?lang=en.

27 Richard E. Neustadt, Presidential Power and the Modern Presidents(1960); Joseph Raz, The Authority of LaW: Essays on LaW and Morality (1979).

28 Jeremy Diamond, Trump: I Could 'Shoot Somebody and I Wouldn't Lose Voters,' CNN, Jan. 24, 2016, https://www.cnn.com/2016/01/23/politics/donald-trump-shootsomebody-support/index.html. 
procedures, these personalization tactics have been especially prominent. Thus, President Trump (in)famously questioned the capacity of Federal District Court judge Gonzalo Curiel to hear a case involving Trump University fairly, on the grounds that the judge was compromised by his purported "Mexican Heritage."29

In a somewhat related vein, critics have charged that the President's pardon of Arizona Sheriff Joseph Arpaio (for a federal contempt of court citation) shortcircuited the usual pardoning process (and Department of Justice guidelines) and undermined judicial authority in order to reward "a political friend and supporter." Even Trump's intermittent claims that his opponent Hillary Clinton was "guilty as hell" and would "go to jail" if Trump were elected president implied that he would substitute his personal judgment for the due process of law. ${ }^{31}$

\section{B. The President's Populist IConoclasm}

The President's well-documented populism is another vector for conflict with courts. While populism is an open, substantively thin ideology, it is distinguished by an anti-elitism in general, and skepticism toward establishment officials and institutions in particular. ${ }^{32}$ In the populist worldview, these organizations and figures impede or obscure the actual wishes of a unified and "authentic people," and only true leaders from outside this system can overcome these enervating forces through political criticism, purification, and even reconstruction. ${ }^{33}$

Trump's articulation of these themes has played a steady part in his campaign and governing rhetoric. For example, his 2016 RNC speech targeted the "[b]ig business, elite media and major donors" who supported Secretary of State Hillary Clinton and betrayed the "American People." These "special interests... rigged our political and economic system for their exclusive benefit." In opposition, Trump promised to serve as a champion for ordinary "[p] eople who work hard but no longer have a voice." ${ }^{34}$ In the days since the GOP Convention in Cleveland, the President and members of his administration have returned to and expanded these anti-elite criticisms, taking aim at the media, the election system, Congress, Republican leadership, and the Department of Justice, among others. ${ }^{35}$

29 Nina Totenberg, Who Is Judge Gonzalo Curiel, The Man Trump Attacked for His Mexican Ancestry? NPR, Jun. 7, 2016, https://www.npr.org/2016/06/07/481140881/ who-is-judge-gonzalo-curiel-the-man-trump-attacked-for-his-mexican-ancestry.

30 L.A. Times, If Trump Pardons Arpaio, He'll Reward Defiance of the Courts, and That's Wrong, Aug. 23, 2017.

31 Yoni Appelbaum, Trump's Promise to Jail Clinton Is a Threat to American Democracy, The Atlantic, Oct. 10, 2016; Tim Murphy, Trump's Call to Imprison Hillary Clinton Was More Than a Year in the Making, Mother Jones, November/December, 2016.

32 Cas Mudde \& Cristóbal Rovira Kaltwasser, Populism: A Very Short Introduction (2017).

33 Jan-Werner Müller, What Is Populism? (2016).

34 See https://www.vox.com/2016/7/21/12253426/donald-trump-acceptance-speechtranscript-republican-nomination-transcript, supra note 25.

35 Katherine Faulders \& Alexander Mallin, President Trump Launches Commission on 'Election Integrity,' ABC News, May 11, 2017, https://abcnews.go.com/Politics/ president-trump-expected-launch-commission-election-integrity/story?id=47337222; Lauren Fox, McConnell Praises Trump in Kentucky, Minutes after Trump Criticized Him, CNN, Aug. 24, 2017, https://www.cnn.com/2017/08/24/politics/mitch-mcconnell- 
This populist strain should also have implications for the administration's treatment of the judiciary. Most obviously, judges and court systems are an enticing target for the President's ongoing disruption of the status quo. This is especially likely for federal courts, staffed by highly educated professionals who are structurally sequestered from political and electoral forces..$^{36}$ Alexis de Tocqueville's contention that judges and lawyers in the United States form an embedded and insulated group that resist democratic impulses and the desired "movements of the social body" highlight how the legal class is ripe for populist targeting. ${ }^{37}$ Indeed, the 2016 Republican Platform (presumably blessed by Mr. Trump, at least in its broad strokes) gave vent to some of these sentiments. It warned "against opportunistic litigation by trial lawyers," and further cautioned that "our country's constitutional order" was threatened by "an activist judiciary that usurps powers properly reserved to the people through other branches of government." 38 The Platform castigated specific Supreme Court decisions (in areas such as abortion, gay rights, and health care) as expanding "the power of the judiciary at the expense of the people" and called on Congress to use impeachment to check unaccountable judges.

\section{Accounting for Presidential Deference}

So far, we have identified a number of factors that would seem to place the Trump administration on a slanted political plane leading straight to confrontations with courts. Increased politicization of the judiciary, deepening partisanship (including a bench closely divided internally by partisan appointments), and, finally, distinctive attributes of the President himself (in particular his personalization of politics and populist flair) all seem to set us up for interbranch confrontations that could challenge long-held norms of judicial independence. ${ }^{39}$ We might add to this observation the President's own declarations that he favors the great "energy" and debate produced by conflict within, and, presumably, between the branches of governance. ${ }^{40}$

So where is the evidence for our anticipated spike in executive-judicial skirmishes? As noted, the 2016 Republican platform was often unsparing in its critique of specific court decisions and judicial "activism." Moreover, the Trump administration has periodically and aggressively responded to what it sees as

breakfast-comments/index.html; Mathew Ingram, President Donald Trump vs. the Media Will Be an Epic Battle, Fortune, Nov. 11, 2016; Matthew Nussbaum \& Elana Schor, Trump Signs Russia Sanctions Bill but Blasts Congress, Politico, Aug. 2, 2017, https://www.politico.com/story/2017/08/02/trump-signs-bipartisan-russia-sanctionsbill-241242.

36 Indeed as Slotnick, Schiavoni, and Goldman note, the profile of Obama's judicial appointees makes them especially salient as populist targets. After all, "some $44 \%$ of the Obama appointees had a prestige legal education," a figure considerably higher than his immediate predecessors. Slotnick et al., supra note 18 at 363.

37 Alexis de Tocqueville, Democracy in America (Harvey C. Mansfield \& Delba Winthrop, trans., Univ. Chicago Press 2000) (1835).

38 The 2016 Republican Party Platform, Jul. 18, 2016, http://www.presidency.ucsb.edu/ ws/index.php?pid=117718.

39 Ming W. Chin, Judicial Independence: Under Attack Again, 61 HAST. L.J. 1345 (2010).

40 Rebecca Ballhaus, Trump Defends West Wing Turnover: 'I Like Conflict,' Wall St. J., Mar. 6, 2018. 
Table 2. Trump Twitter References to Courts and Congress (January 20, 2017-March 15, 2018).

\begin{tabular}{|c|c|c|c|c|}
\hline Search Terms: & $\begin{array}{c}\text { Neutral/Descriptive } \\
\text { references }\end{array}$ & $\begin{array}{c}\text { Positive } \\
\text { references }\end{array}$ & $\begin{array}{c}\text { Negative references } \\
\text { [without travel ban } \\
\text { references] }\end{array}$ & Total \\
\hline $\begin{array}{c}\text { "court;" "judge;" } \\
\text { "justice" }\end{array}$ & $\begin{array}{c}47 \% \\
\mathrm{n}=23\end{array}$ & $\begin{array}{l}18 \% \\
\mathrm{n}=9\end{array}$ & $\begin{array}{l}35 \%[14 \%] \\
\mathrm{n}=17[\mathrm{n}=7]\end{array}$ & $\begin{array}{c}100 \% \\
\mathrm{n}=49\end{array}$ \\
\hline $\begin{array}{c}\text { "Congress;" } \\
\text { "Senate;" } \\
\text { "Representative;" } \\
\text { "Sen.;" "Rep.;" }\end{array}$ & $32 \%$ & $35 \%$ & $32 \%$ & $99 \%$ \\
$\mathrm{n}=75$ & $\mathrm{n}=81$ & $\mathrm{n}=75$ & $\mathrm{n}=231$ \\
\hline
\end{tabular}

Source: Trump Twitter Archive (http://www.trumptwitterarchive.com/archive)

unfavorable rulings, especially where the courts have issued judgments against the President's immigration and travel restrictions (and, by extension, decisions that purportedly impede his anti-terrorism initiatives). ${ }^{41}$ For example, White House policy adviser Stephen Miller criticized the Ninth Circuit Court of Appeals ruling against reinstating the President's "travel ban" (which had been blocked by a District Court judge in Washington State) as a "judicial usurpation of power." 42

Notwithstanding these and other challenges, however, we have good reasons for thinking they represent less than meets the eye. A review of the official White House search engine finds, for example, no administration reference to "judicial activism" or "legislating from the bench," two charges that were popular under recent prior Republican administrations. More systematically, if we look at the President's favored communication method, Twitter, we find relatively infrequent references to courts and judges, and, particularly if we exclude tweets targeting the travel ban rulings, a mix of positive and negative statements. Table 2 summarizes the President's tweets over his first sixty weeks in office in which he mentions, respectively courts, judges, or Justices on the one hand, and Congress and lawmakers on the other.

On the whole, these results do not give us a picture of a president spoiling for a fight with the judiciary. Indeed, the President effusively praised deceased Supreme Court Justice Antonin Scalia, as well as his successor, Trump's appointee Neil Gorsuch (whose seating the President regularly identifies as one of his signature accomplishments). Three months after Gorsuch joined the Court, the president followed a nearly identical pattern with his next nominee to the nation's highest court. Thus, he hailed both retiring Justice Anthony Kennedy (as a public servant associated with "incredible passion and devotion... [and a] lifetime of distinguished

${ }_{41}$ Brent Kendall, Trump Says Judge's Mexican Heritage Presents 'Absolute Conflict,' Wall St. J., June 3, 2016.

42 Philip Rucker, Stephen Miller Says White House Will Fight for Travel Ban, Advances False Voter Fraud Claims, Wash. Post, Feb. 12, 2017. More recently, the President chastised both a federal District Court judge, who had placed a temporary hold on an executive branch order barring some immigrant asylum seekers, and the Ninth Circuit (as "a big thorn in our side"). Kate Sullivan and Paul LeBlanc, Trump calls 9th Circuit a 'big thorn in our side, 'accuses judges of imperiling US security, CNN, Nov. 22, 2018, https:// www.cnn.com/2018/11/22/politics/trump-chief-justice-john-roberts-judges/index.html. 
service"), ${ }^{43}$ and his eventual, controversial replacement, appeals court judge Brett Kavanaugh (a "brilliant jurist... universally regarded as one of the finest and sharpest legal minds of our time"). ${ }^{44}$

Even some of the President's "neutral" or non-valenced remarks about the judiciary imply a willingness to recognize the courts, and especially the Supreme Court, as a legitimate if not authoritative forum for conflict resolution. As the President indicated in a February 20, 2018 tweet, he hoped Republicans would challenge a Pennsylvania redistricting map, taking it "all the way to the Supreme Court, if necessary." ${ }^{45}$ At times, the President has communicated a cautious deference with respect to the judiciary and gun control. As the President put it in a March 12 tweet: "On 18 to 21 Age Limits, [I am] watching court cases and rulings before acting." ${ }^{\prime 4}$ Perhaps most importantly, despite sometimes intemperate remarks about judges and judicial decisions coming from the President and his staff, these rhetorical jabs have, so far, not been joined by either sustained institutional criticism or specific proposals for court-curbing or other sanctions.

As indicated, all of this is somewhat surprising. Given the heated state of judicial politics generally, and President Trump's enthusiasm for battling other institutions of government and civil society more specifically, why hasn't the current administration fostered a less hospitable landscape for judges, courts, and judicial independence?

One initial response is not very satisfying: the President is reluctant to take on a branch that still enjoys relatively high diffuse, institutional support, especially relative to Congress and even the executive branch. ${ }^{47}$ But such a response presumes that the President thinks in institutional terms, and has a resulting sense of humility and an inclination to defer to a more popular branch. These conclusions aren't obviously supported by his behavior, demeanor, or the terms under which he assumed power. ${ }^{48}$

43 The White House, Remarks by President Trump Announcing Judge Brett M. Kavanaugh as the Nominee for Associate Justice of the Supreme Court of the United States, Jul. 9, 2018, https://www.whitehouse.gov/briefings-statements/remarks-president-trump-announcingjudge-brett-m-kavanaugh-nominee-associate-justice-supreme-court-united-states//.

44 Id.

45 Donald J. Trump (@realDonaldTrump), Twitter (Feb. 20, 2018, 5:11 AM), https:// twitter.com/realdonaldtrump/status/965937068907073536?lang=en.

46 Donald J. Trump (@realDonaldTrump), Twitter (Mar. 12, 2018, 6:22 AM), https:// twitter.com/realdonaldtrump/status/973187513731944448?lang=en

47 Gregory A. Caldeira, Neither the Purse Nor the Sword: Dynamics of Public Confidence in the Supreme Court, 80 Am. Pol. Sci. Rev. 1209 (1986); Lydia Saad, At 13\%, Congress' Approval Ties All-Time Low. Republicans and

Democrats Give Identical Ratings to the Divided Congress, Gallup News Service, Oct. 12, 2011, https://news.gallup.com/poll/150038/Congress-Approval-Ties-Time-Low. aspx; Georg Vanberg, Legislative-Judicial Relations: A Game-Theoretic Approach to Constitutional Review, 45 Am. J. Pol. ScI. 346 (2001).

48 Clare Malone, Americans Don't Trust Their Institutions Anymore, Fivethirtyeight. com, Nov. 16, 2016, https://fivethirtyeight.com/features/americans-dont-trust-theirinstitutions-anymore/. 


\section{A. EXECUTIVE INTERESTS AND INDEPENDENT COURTS}

A related, and more plausible hypothesis is that the administration is somewhat reluctant to take on the judiciary in any sustained way because it understands, on some level, that independent courts, judicial review, and even periods of judicial activism (understood here as regular court invalidation of government action) may serve executive branch interests. In the scholarly literature, such an argument usually takes one of two basic forms. First, relatively strong and independent courts could be a way of navigating controversial and crosscutting party issues. As Mark Graber has explained, elected officials may look to the judiciary to resolve or temper disruptive political topics, with the hope that courts will remove the underlying contentious issue by withdrawing it to a judicial forum supposedly beyond the reach of ordinary politicians. ${ }^{49}$

A second take on the judiciary as incipient ally model understands the courts as a "vehicle of regime enforcement" or potential institutional capture.$^{50}$ In this view, presidents rely on courts to help them entrench power and strengthen governing coalitions. More specifically, scholars like Stephen Skowronek and Keith Whittington argue that favorable court rulings help presidents affiliated with an existing regime maintain their legal, policy, and ideological commitments through time, even in the face of dwindling or unstable political prospects. ${ }^{51}$ As Whittington points out, "the law is intertemporal and partially incongruent with the current regime, and as such it may provide shelter from the prevailing political winds" or even help "resist the momentum of, or open fissures within, the dominant regime." ${ }^{2}$ There is evidence of such a strategy in the Trump administration's early enthusiasm for seeding the bench with young, conservative appellate appointments who can make the greatest policy impact for the longest time..$^{53}$

But both of these explanations for the (relative) comity of the Trump administration towards the judiciary are imperfect. With respect to the "issue displacement" thesis, we might note that the President has energetically stoked some crosscutting policy disputes within his party, often in ways that threaten to introduce or at least exacerbate intra-party tensions. For example, we can see some of these inflammatory dynamics in the President's statements about abortion as well as in his economic nationalism generally, and, more particularly, in his

49 Mark Graber, The Non-Majoritarian Problem: Legislative Deference to the Judiciary, 7 Stud. Am. Pol. Dev., 35 (1993). See also George I. Lovell, Legislative Deferrals: Statutory Ambiguity, Judicial Power, and American Democracy (2003); J. Mitchell Pickerill, Constitutional Deliberation in Congress: The Impact of Judicial Review in a SeParated System (2004).

50 Whittington, supra note 17 at 593.

51 Stephen Skowronek, The Politics Presidents Make: Leadership from John Adams to George Bush (1997); Keith E. Whittington, Political Foundations of Judicial Supremacy The Presidency, the Supreme Court, and Constitutional Leadership in U.S. History (2007). See also Ran Hirschl, Towards Juristocracy: The Origins and Consequences of the New Constitutionalism (2004); Howard Gillman, How Political Parties Can Use the Courts to Advance Their Agendas: Federal Courts in the United States, 1875-1891, 96 Am. Pol. ScI. Rev. 511 (2002).

52 WhitTington, supra note 51 at 167.

53 Charlie Savage, Courts Reshaped At Fastest Pace In Five Decades, N.Y. Times, November 12, 2017, at A1. 
imposition of protective tariffs on a variety of raw materials and manufactured products. ${ }^{54}$ Stated differently, if the Trump administration has an inclination to cede some controversial topics to the judiciary, it's not obvious what these subjects of avoidance actually are.

As to whether Trump might be reluctant to target the judiciary on the grounds that it can help secure his party's legacy in the face of future electoral defeats, this case is stronger but still uncertain. Undoubtedly, there is some evidence the administration is pursuing this sort of long game with its appointments strategy. ${ }^{55} \mathrm{On}$ the other hand, one might note that Trump is the wrong sort of candidate to fit into the classic regime preservation framework articulated by scholars like Skowronek. As Whittington points out, presidents are most likely to use a hedge your bets strategy when they are "affiliated" leaders "who must manage an established but fractious political coalition while advancing the contested ideological commitments of the [existing] political regime." "56 But Trump's loyalty to his inherited Republican regime is shallow at best. He is no establishment Republican, and has been critical of his party's congressional and national leadership, and, as noted, on some important, historic GOP positions he has shown a readiness to deviate from party orthodoxy.

For these and other reasons, some scholars have suggested Trump might be better seen as what Skowronek calls a "disjunctive" president - a Chief Executive with little allegiance to the prevailing governing coalition, but a figure who tries, nevertheless, to hold it in place in the face of building political strains. ${ }^{57}$ But even this description, which holds that Trump is more like Jimmy Carter than Ronald Reagan, fits the President inadequately. ${ }^{58}$ Describing Trump as a disjunctive leader fails to capture his iconoclasm, populism, and other idiosyncratic characteristics that don't easily square with the prevailing Republican ideology, even though they are signature elements of the President's governing style. In other words, trying to place Trump into a scheme of regime politics - where the president is either operating within the parameters of an established philosophy of governance, or trying to smash it and forge his own-doesn't reflect his ideological flexibility, political opportunism, and the degree to which his political approach bears a personal, sui generis stamp. Trump seems to favor his judicial appointments for personal reasons, reflected distinction, and political payoff, and not for advancing deeply seated and long term ideological commitments.

\section{B. Personal Familiarity and Past Reliance}

Given the shortcomings of these explanations, we need to adopt a different tack. At an individual level, we might speculate that Trump's hesitancy to criticize courts could be a byproduct of familiarity. While the President has never sat in public office before occupying the White House, he has repeatedly relied on lawyers and the judiciary in his prior business career and personal life. His administration's

54 Jonathan D. Moyer \& David K. Bohl, Why Trump’s Tariffs Could Weaken U.S. Influence in the World, WASH. Post, March 12, 2018.

55 Savage, supra note 53.

56 Whittington, supra note 17, at 594.

57 SKOWRONEK, supra note 51, at 39.

58 Scott Lemieux, Is Donald Trump the Next Jimmy Carter?, The New Republic, Jan. 23, 2017. 
zealous use of nondisclosure agreements amongst aides and other government employees suggests a comfort with litigious protections as a partial substitute for interpersonal trust. ${ }^{59}$

Moreover, although he has been the target of thousands of lawsuits, Trump has frequently prevailed, and, more generally, has turned to courts, litigation, and other legal transactions to protect his financial and individual interests. ${ }^{60}$ Despite his protestation in his 1987 memoir, The Art of the Deal that "I don't like lawyers," the book details Mr. Trump's reliance on attorneys to navigate deals and protect his personal assets, and he describes their work in often flattering terms.$^{61}$ Moreover, the nature of the attorney-client relationship is one that produces an explicit, contractual loyalty of the sort that the President purportedly prizes. ${ }^{62}$

\section{PARTisan Disequilibrium and the Courts}

Still another explanation for the administration's unexpected restraint when it comes to courts may be the most powerful. While admittedly preliminary, some recent work finds teasing indications of partisan and ideological disequilibrium with respect to longstanding perceptions of the courts. ${ }^{63}$ As we saw, Table 1 serves as evidence of partisan politicization of courts in the twenty-first century- that is, it corroborates the idea that the two major parties have been increasingly willing to take on judicial decisions and legal controversies as part of their major policy agendas. But a more historical and nuanced consideration reveals a different and more dynamic picture.

Consider, in this regard, the trend lines revealed in Figure 2. This figure lays out what Democratic and Republican party platforms have had to say with respect to the judiciary for every four-year cycle from 1948 to 2016. Until the 1976 platform, both Democrats and Republicans appear to have been deferential to courts in these official party statements, generally avoiding reference to the judiciary entirely. Beginning in 1976, however, we can detect a notable shift in party attitudes, especially for Republicans. GOP platforms became increasingly detailed and negative in discussing courts and judges over this period (while Democrats continued to give judicial politics a low profile). Thus, with the exception of 1984, every Republican platform from 1976 has made at least some negative reference

59 Josh Dawsey \& Ashley Parker, 'Everyone Signed One': Trump Is Aggressive in His Use of Nondisclosure Agreements, Even in Government, Wash. Post, Aug. 13, 2018, https://www.washingtonpost.com/politics/everyone-signed-one-trump-is-aggressive-inhis-use-of-nondisclosure-agreements-even-in-government/2018/08/13/9d0315ba-9f1511e8-93e3-24d1703d2a7a_story.html?utm_term=.a8e2477272f2.

60 Ben Terris, Lawyers upon Lawyers upon Lawyers: In Trump World, Everyone Has an Attorney, Wash. Post, July 26, 2017.

61 Donald J. Trump \& Tony Schwartz, Trump: The Art of the Deal (1987).

62 Jonathan Mahler, All the President's Lawyers, N.Y. Times Magazine, July 9, 2017, at 28.

63 Charles Babington, GOP Is Fracturing over Power of Judiciary, WASH. Post, Apr. 7, 2005 at A04; Neal Devins \& Lawrence Baum, Split Definitive: How Party Polarization Turned the Supreme Court into a Partisan Court, 2016 Sup. Cт. Rev. 301 (2017); Ryan Grim \& Sam Stein, A New Love Affair: Republicans Rally to Defend Judges, Hufrington PosT, Apr. 5, 2012, http://www.huffingtonpost.com/2012/04/05/republicans-judgessupreme-court_n_1406580.html. 
Figure 2. Negative and Positive Statements about Courts in Major Party Platforms (1948-2016).

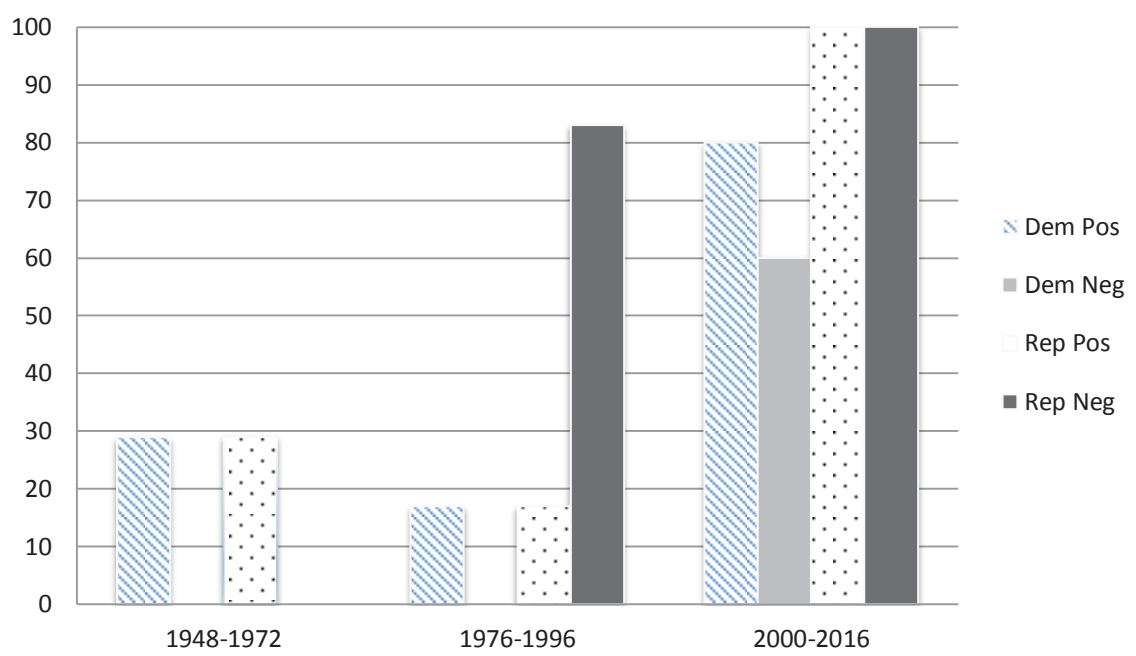

Source: The American Presidency Project (http://www.presidency.ucsb.edu/)

to courts and judges. These statements have objected to specific court decisions in such areas as prayer in school, criminal justice, and, of course, abortion. In addition, beginning with the 1980 platform, the GOP also began calling for the appointment of judges whose rulings would be consistent with their policy and ideological goals. In contrast, Democratic platforms from 1976 through 1996 were mostly silent with respect to courts, reflecting the party's resistance to having courts enter into national politics, its basic contentment with the judiciary's role in policymaking, or, most likely, both.

But as Figure 2 suggests, at least with respect to party platforms, this pattern of active Republican skepticism towards judicial authority and quiet Democratic complicity started to change in the twenty-first century. In our new century (significantly framed by the 2000 decision Bush v. Gore and the litigation and appointment successes of the Federalist Society and other organizations), ${ }^{64}$ Republicans have been more willing than in the past to praise the judiciary and hail individual court decisions. Moreover, especially over the past decade, Democrats have shown some early signs of being less secure about their historic institutional alliance with courts. The gradual rise of what Steven Teles has called the "conservative legal movement" 65 in the 1970s (in which conservatives combined a plan for staffing the courts with strategies for using litigation to roll back liberal policies) helped unsettle partisan and ideological attitudes towards independent courts, which had been mostly intact following New Deal. ${ }^{66}$

64 Jeffrey Toobin, The Conservative Pipeline to the Supreme Court, ThE New Yorker, Apr. 17, 2017.

65 Steven M. Teles, The Rise of the Conservative Legal Movement: The Battle for Control of the LaW 2 (2010).

66 Larry Kramer, The People Themselves: Popular Constitutionalism and Judicial REVIEW 218-220 (2004) (discussing the New Deal "settlement"). 
Today, while liberals fret about such issues as the future of constitutionally protected abortion, affirmative action, civil rights, and campaign finance, many conservatives and Republicans see the courts entering favorable rulings on questions of federal power (United States v. Lopez, ${ }^{67}$ City of Boerne v. Flores, ${ }^{68}$ United States v. Morrison ${ }^{69}$ ), voting rights (Shelby County v. Holder ${ }^{70}$ ) and even civil liberties (District of Columbia. v. Heller, ${ }^{71}$ McDonald v. Chicago, ${ }^{72}$ Citizens United v. Federal Election Commission ${ }^{73}$ ). All of this has contributed to a climate in which the two major political parties, already at important crossroads with respect to their own ideological and policy futures, are doubly unsteady when it comes to assessing a complex, shifting, and unreliable federal judiciary. For the moment, broad institutional attacks against the courts (from either party) have given way to more opportunistic, transactional, and issue based litigation and policy campaigns.

In sum, a possible explanation for the relative reticence of this administration (and its congressional and interest group allies) to engage and criticize the inherited "Obama judiciary," is a perfect storm of political forces, including the competitiveness of national elections, the finely tuned partisan balance in the court system, and ideological uncertainty in both major parties about the judiciary's future direction. In the case of the GOP in particular, this ambiguity has been further clouded by the new political strains introduced by President Trump. The President's populist and nationalist flair, mercurial policy preferences, and personal governing style don't easily comport with the mainstay leaders and ideological groups that traditionally comprised the Republican party-social culture warriors, fiscal conservatives, and libertarians. ${ }^{74}$

Occam's razor requires that we identify one other explanation for the (temporary) low-boil of executive-judicial relations. As noted earlier, President Trump has been especially vociferous and ebullient in speaking about his judicial nominees and then appointments. He hailed his first Supreme Court appointment, Neil Gorsuch, as "one of the most qualified people ever to be nominated for this post," 75 identifying him as "a man of great and unquestioned integrity." "T6 The President has further gushed that the "best moment" of his presidency (so far) has been his successful appointment of Gorsuch, "a real legacy in a certain way, very important." ${ }^{\text {77 }}$ The President sounded similar triumphant notes in lauding his

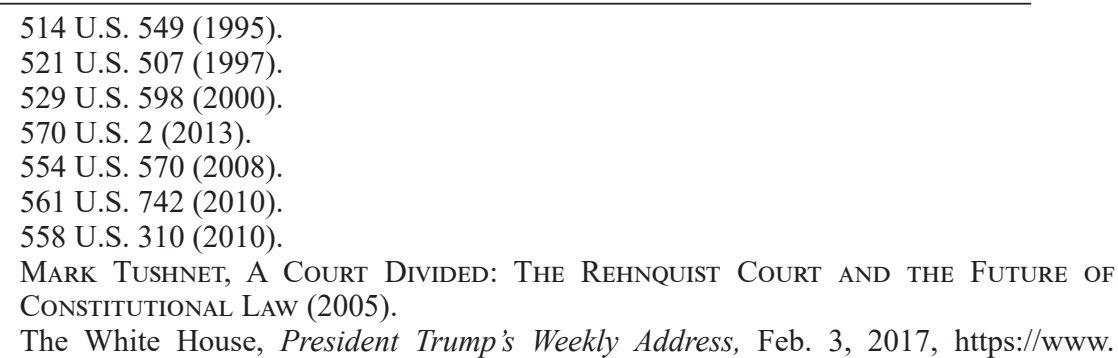
whitehouse.gov/briefings-statements/president-trumps-weekly-address/.

76 The White House, Remarks by President Trump and Justice Gorsuch at Swearingin of Justice Gorsuch to the Supreme Court, Apr. 10, 2017, https://www.whitehouse. gov/briefings-statements/remarks-president-trump-justice-gorsuch-swearing-justicegorsuch-supreme-court/.

77 Jake Miller, Trump: Putting Gorsuch on Supreme Court "Best Moment" of First 100 Days, CBS News, May 1, 2017, https://www.cbsnews.com/news/trump-putting- 
second Court appointee, Brett Kavanaugh. ${ }^{78}$ More generally, the President has communicated a sense that his judicial appointments overall have been effective and marked by excellence. As he tweeted in November 2017, "we are appointing high-quality Federal District...and Appeals Court Judges at a record clip! Our courts are rapidly changing for the better!"79

Seen in this light, the federal judiciary is a positive reference point for the President. Especially since the U.S. Senate has now ushered in a post-"nuclear" age (in which all federal judicial nominees can be confirmed with a simple majority vote), the prospect of future court appointments may strike the President as especially enticing - a political task where Trump will face relatively little opposition, and can claim individual success. With both a cooperative Republican Senate and a list of pre-screened jurists on hand, ${ }^{80}$ the President can expect judicial appointments to be gratifying and fairly smooth (particularly in contrast with a lawmaking process that now includes a hostile and Democratic House of Representatives) ${ }^{81}$ Such dynamics allow the President to emphasize a personal connection to power and foster positive associations with the courts, as an institution he can depict as a direct extension of himself.

\section{ForeCASTING the FUtURE}

We can distill three basic components of the argument so far: First, given the national climate of partisanship, growing politicization of courts, and distinctive features of Trump's claims to power and overall stance towards governing, we had good reasons to think that his administration would usher in a period of increased combativeness with respect to courts and judges. Second, notwithstanding this context, we do not find, in the early Trump years, an especially contentious set of statements (or legislative proposals) regarding specific court decisions, judicial independence, or the judiciary as an institution. This relative deference (even, or especially, in the face of some unfavorable rulings) stands in contrast with the President's statements about other "opponents" (including the "deep state" and the news media).

But the third major claim in this piece is that we can perhaps best understand this otherwise puzzling phenomenon by appreciating the complex mix of the President's personal experiences with law and courts, the tightly competitive state of national politics, unstable attitudes towards the judiciary, and shifting

gorsuch-on-supreme-court-best-moment-of-first-100-days/.

78 The White House, President Donald J. Trump Announces Intent to Nominate Judge Brett M. Kavanaugh to the Supreme Court of the United States, https://www.whitehouse.gov/ presidential-actions/president-donald-j-trump-announces-intent-nominate-judge-brettm-kavanaugh-supreme-court-united-states/.

79 Donald J. Trump (@realDonaldTrump), Twitter (Nov. 1, 2017, 3:03 PM), https://twitter. com/realDonaldTrump/status/925845735089889280.

80 Zoe Tillman, After Eight Years On The Sidelines, This Conservative Group Is Primed To Reshape The Courts Under Trump, BuzzFeed News, Nov. 20, 2017, https:// www.buzzfeednews.com/article/zoetillman/after-eight-years-on-the-sidelines-thisconservative-group.

81 Peter Overby, Democrats Vow to Rein in Trump Administration if they Win the House, NPR, Oct. 24, 2018, https://www.npr.org/2018/10/24/657477478/democrats-vow-torein-in-trump-administration-if-they-win-the-house. 
ideological commitments in the major political parties. We might also note that the recently lowered barriers to judicial appointments in the Senate have induced some Republicans to think of the judiciary in especially opportunistic terms. ${ }^{82}$

What is the wider significance of these claims? To begin with, one must concede that over the course of any administration, and, no doubt, during the Trump years in particular, interbranch armistices are fragile. As argued, given our current context of both ideological flux and major party uncertainty regarding a judiciary that is fairly balanced with respect to partisan appointments, it seems difficult to imagine that courts will consistently chafe against the elected branches over the next few years, especially if Republicans remain in power. But it also does not require great imagination to envision a controversial court decision in the area of, say, immigration or national security, or perhaps a judgment against one of the President's advisors (or family members), triggering a vituperative response from Mr. Trump and his allies. So far, Trump's disruptive demeanor has been fairly restrained when it comes to judges and courts, but he could easily find a pretext for shattering this rapprochement.

It is also an open question whether the President's unconventional governing style and ideological orientation will carry over in important ways to his judges. In particular, will the President's new federal appointees represent a different breed of appointees? Could they, for example, be more apt to give expression to populist values, or communicate directly with the public through new media, or perhaps assume a more confrontational stance with respect to their colleagues on the bench and in the other branches of government. ${ }^{83}$ In other words, will the President's new appointments reflect his assertive and unsettling style — and perhaps challenge existing legal norms regarding such matters as institutional deference, formality, professional ethics, judicial temperament, and a commitment to interstitial (case-based) change?

While it is far too early to say anything meaningful about this question, we can note that several of the President's early nominees possess a different background and character than appointments of the past. They are less demographically diverse, less experienced, and potentially more willing to speak out against perceived mistakes by the judiciary itself. ${ }^{84}$ In this regard, we should not forget Trump's promise to find judges in the mold of the blunt and belligerent Scalia, nor ignore the fact that the 2016 Republican Platform quoted Scalia extensively in deriding the same sex marriage case Obergefell $v$. Hodges ${ }^{85}$ In a related instance of using judges to criticize other judges, the Trump administration highlighted three dissenting opinions from Washington v. Trump (the Ninth Circuit travel ban case from March 2017)..$^{86}$

The final point one should note about the future of executive-judicial relations in the Trump era is the most important one: on a daily basis, the administration is

\footnotetext{
Savage, supra note 53.

Shira Scheindlin, Trump's Crazy Choices for the Courts, N.Y. Times, Nov. 9, 2017.

84 Alliance for Justice, Hearing Does Not Allay Concerns About Bush, Schiff, June 14, 2017, https://www.afj.org/blog/hearing-does-not-allay-concerns-about-bush-schiff; Daniel Politi, Senate Panel Votes to Turn Blogger Without Trial Experience Into a Federal Judge, Slate, Nov. 11, 2017, http://www.slate.com/blogs/the_slatest/2017/11/11/ senate_panel_approves_brett_j_talley_a_lawyer_without_trial_experience_for.html.

85576 U.S.

$86 \quad 847$ F.3d $\overline{115} 1$.
} 
laying down precedents in our brave new "post-nuclear" world. As noted, some commentators have already reported that the new administration is pursuing an especially aggressive and partisan appointments strategy, taking advantage of the distinct opportunity created by a stockpile of conservative candidates coming of age alongside the newly permissive Senate rules. These rules have already eliminated the judicial filibuster and may weaken or eliminate the "blue slip" process through which Senators can block a nominee from their own state. ${ }^{87}$ In any event, today's court appointments require less comity, accommodation, and bipartisanship than they enjoyed in the past. Thus, the decisions of both the Trump White House and Senate leaders over the next few years will go a long way to establishing both the character of the federal bench and the future tenor of the politics of judicial nominations. Will the manner in which we select our judges and justices reflect some sense of shared professionalism and a common commitment to due process, or will it become even more hardball, bitter, and uncompromising? ${ }^{88}$

The latter outcome threatens to leave the judiciary understaffed and dysfunctional during periods when the Senate and president are of different parties, and "as polarized as the rest of the country" when the process runs smoothly but stocks the courts with increasingly ideological and extreme appointees. ${ }^{89}$ This prospect should fill us with alarm, not only because it continues the trends of hyperpartisanship and division that have marred the twenty-first century, but because it threatens the very legitimacy of our courts.

As the legal scholar Tom Tyler has shown, people consider the judiciary a unique and authoritative forum for settling social conflicts. We accept the courts' judgments, even when they seem to go against our own personal interests, because we have public trust in our judges and their commitment to a procedural justice that provides everyone with a genuine and meaningful voice, and the right to be treated with impartiality and respect regardless of race, class, gender, or party. ${ }^{90}$ But when we start to see the courts as just another venue for advancing the ideologies and preferences of party leaders, we run the risk of losing our faith in the law as a forum of principle, stability, and fairness.

Savage, supra note 53.

88 Mark V. Tushnet, Constitutional Hardball, 37 John Marshall L. Rev. 523 (2004).

89 Savage, supra note 53.

90 See Tom R. Tyler, Why People Obey the LaW (1990). 